\title{
Chronic inflammatory demyelinating polyneuropathy with anti-contactin-associated protein 1 antibody and bile duct hamartomas in the liver: a case report
}

\author{
Shurong $\mathrm{Hu}^{1+}$, Yin $\mathrm{Hu}^{2 \dagger}$ and Qiang $\mathrm{Du}^{2^{*}}$
}

\begin{abstract}
Background: Autoantibodies targeting node of Ranvier proteins are rarely reported in China.

Case presentation: We present the case of a 66-year-old Chinese man who concomitantly developed chronic inflammatory demyelinating polyneuropathy with anti-contactin-associated protein 1 antibody and bile duct hamartomas in liver, which are rarely reported in China. The man presented with chronic progressive sensory and motor symptoms, bilateral periphery facial paralysis, and protein-cell dissociation of cerebrospinal fluid. Nerve conduction study indicated demyelinating neuropathy. Enhanced magnetic resonance imaging of the liver showed diffuse intrahepatic lesions, which were considered as bile duct hamartomas in the liver. He was suspected as having chronic inflammatory demyelinating polyneuropathy and treated with intravenous immunoglobulin and prednisone. However, his condition got worse. One month later, he was diagnosed with chronic inflammatory demyelinating polyneuropathy associated with anti-contactin-associated protein 1 antibody. He received high-dose methylprednisolone, followed by standard plasma exchange and rituximab therapy. His sensory and motor manifestations were significantly improved at 1 year of follow-up.
\end{abstract}

Conclusions: This case reminds clinicians to be aware of antiparanodal antibodies, which are associated with specific phenotypes and therapeutic response.

Keywords: Chronic inflammatory demyelinating polyradiculoneuropathy, Autoantibody, Contactin-associated protein 1, Bile duct hamartomas in liver

\section{Background}

Chronic inflammatory demyelinating polyneuropathy (CIDP) is a heterogeneous chronic autoimmune neuropathy characterized by chronic progressive motor and sensory deficits during a period of at least 8 weeks

\footnotetext{
*Correspondence: duqiang0510@zju.edu.cn

†Shurong Hu and Yin Hu contributed equally to this paper

2 Department of Neurology, The Second Affiliated Hospital, Zhejiang

University School of Medicine, 88 Jiefang Road, Hangzhou 310000, Zhejiang, China

Full list of author information is available at the end of the article
}

$[1,2]$. CIDP diagnosis is based on clinical and electrophysiological criteria [2]. Humoral factors are involved in the mechanisms. Intravenous immunoglobulin has been established as the first-choice treatment for CIDP. Other treatments, including corticosteroid and plasma exchange are also applicable [3]. In recent years, autoantibodies targeting node of Ranvier proteins such as contactin-1 (CNTN1), contactin-2 (CNTN2), contactinassociated protein 1 (Caspr1), neurofascin 155 (NF155), and neurofascin 186 (NF186) have been detected in a small subset of patients with CIDP, which disrupt axoglial junctions at nodes or paranodes [4-6]. However, these original author(s) and the source, provide a link to the Creative Commons licence, and indicate if changes were made. The images or other third party material in this article are included in the article's Creative Commons licence, unless indicated otherwise in a credit line to the material. If material is not included in the article's Creative Commons licence and your intended use is not permitted by statutory regulation or exceeds the permitted use, you will need to obtain permission directly from the copyright holder. To view a copy of this licence, visit http://creativecommons.org/licenses/by/4.0/. The Creative Commons Public Domain Dedication waiver (http://creativeco mmons.org/publicdomain/zero/1.0/) applies to the data made available in this article, unless otherwise stated in a credit line to the data. 
antibodies against the node of Ranvier proteins are rare [7]. To our knowledge, no cases of CIDP with anti-Caspr1 have been previously reported in Chinese patients.

\section{Case presentation}

We present the case of a 66-year-old Chinese male patient with no previous relevant history or family history of neurological disease. He initially noticed numbness of the feet and weakness of the legs. Two months later, the numbness spread to his thigh root, followed by weakness and numbness of his hands. Subsequently, he presented with gait ataxia and distal limb numbness. Therefore, he went to a local hospital for help. He showed mild facial bilateral paralysis. As his symptoms worsened, it was difficult for him to walk without assistance. Clinical examination showed that muscle weakness and sensory disturbance were observed in the distal parts of all limbs. In a manual muscle strength test, his upper limb muscle strength was grade 4 and lower limb muscle strength was grade 3. Deep tendon reflexes had disappeared in all limbs and no muscle atrophy was observed. No other abnormalities were found in the patient's cranial nerves or autonomic nervous system. A head computerized tomography (CT)-scan was normal. He then underwent a lumbar puncture, which revealed albuminocytological dissociation, with protein concentration of $2.78 \mathrm{~g} / \mathrm{L}$ and 2 cells / $\mu$ l. Electromyography showed that sensory nerve conduction was prolonged in the upper and lower limbs, while motor nerve conduction and F-wave latency was prolonged in the upper limbs and disappeared in the lower limbs. Lumbar spine magnetic resonance imaging (MRI) showed mild herniated disc at lumbar segments 4 and 5 (L4-L5) and lumbar segment 5 and sacral segment 1 (L5-S1). Cervical spine MRI showed mild herniated disc at cervical segment 3-6 (C3-C6). The thorax-abdomen-pelvis $\mathrm{CT}$ scan detected no malignancy. A biochemical examination revealed no abnormal findings, with the exception of low hemoglobin (124 g/L), low albumin $(30.4 \mathrm{~g} / \mathrm{L})$, high cholesterol $(7.13 \mathrm{mmol} / \mathrm{L})$, and high D-Dimer $(1.48 \mathrm{mg} / \mathrm{l})$. The results of screening tests for human immunodeficiency virus, syphilis reaction, antineutrophil cytoplasmic antibody (ANCA), antinuclear antibody (ANA), common cancer markers, and lead level were negative. The patient's levels of creatine kinase and vitamins B1, B12, and E were normal. Other normal or negative antibody tests included myelin basic protein (MBP), myelin oligodendrocyte glycoprotein (MOG), aquaporin-4 (AQP4), antibodies associated with paraneoplastic neurological syndromes (PNS), and antiganglioside complex antibody profiles. He was suspected as CIDP and treated with intravenous immunoglobulin $(0.4 \mathrm{~g} / \mathrm{kg} /$ day for five consecutive days) and prednisone tablets $40 \mathrm{mg}$ daily. The symptoms got worse after 1 month of therapy.

The patient was then admitted to our hospital. He complained that sensory symptoms of numbness were more prominent than his motor weakness. Physical examination revealed bilateral periphery facial paralysis, decreased temperature of the limb extremities, reduced pinprick and vibration sense, absent reflexes of both the upper and lower extremities, and an unsteady gait. Muscle strength was grade 3 in the upper and lower limbs. Nerve conduction studies showed motor and sensory demyelinating neuropathy in the upper and lower limbs (Table 1). Deep venous thrombosis was found in the right lower extremities by ultrasonography. Whole body positron emission tomography (PET)-CT scan showed diffuse low-density nodules in the liver without high glucose metabolism, which probably indicated benign lesions, bilateral renal cysts, and spinal degeneration. Enhanced MRI of the liver showed diffuse intrahepatic lesions, which were considered bile duct hamartomas in the liver (Fig. 1).

The patient was diagnosed as definite CIDP, referring to the diagnostic criteria of European Federation of Neurological Societies/Peripheral Nerve Society (EFNS/PNS) [8]. The patient's lack of response to intravenous immunoglobulins prompted us to consider autoantibodies targeting node of Ranvier proteins. Therefore, the serum sample was tested for auto antibodies against Ranvier proteins, including NF155, NF186, CNTN1, CNTN2, and Caspr1 [9]. Finally, the antibody test was positive for anti-Caspr1 antibodies (1:1000) (Fig. 2). We made the diagnosis of CIDP associated with anti-Caspr1 antibody. Then the patient received high-dose methylprednisolone, followed by standard plasma exchange and rituximab therapy. The patient's sensory and motor manifestations were significantly improved at 1 year follow-up.

\section{Discussion}

We report herein a patient with CIDP serology positive for anti-Caspr1 antibody in China. Worldwide, the frequency and symptoms of patients with auto antibodies against the nodal/paranodal proteins indicate significant variability between different countries, which may be caused by the various methods used for antibody detection [2]. Up to now, only a few patients have been reported with anti-Caspr1 antibodies, validating the rare presence in CIDP [10]. Caspr1 antibodies 
Table 1 Selected nerve conduction study performed at the time of diagnosis in our hospital

\begin{tabular}{|c|c|c|c|}
\hline & Onset latency (ms) & Amplitude (mV) & Conduction velocity $(\mathrm{m} / \mathrm{s})$ \\
\hline \multicolumn{4}{|l|}{ Motor nerves } \\
\hline Right median nerve (wrist) & 7.01 & 2.74 & 23.3 \\
\hline Right median nerve (elbow) & 15.9 & 2.62 & 21.2 \\
\hline Right ulnar nerve (wrist) & 5.29 & 1.91 & Too low to calculate \\
\hline Right ulnar nerve (elbow) & 14.4 & 2.94 & 23.1 \\
\hline Right tibial nerve (knee) & No response & No response & Too low to calculate \\
\hline Right common peroneal (knee) & 14.3 & 0.052 & Too low to calculate \\
\hline \multicolumn{4}{|l|}{ Sensory nerves } \\
\hline Right median nerve & 9.08 & 1.4 & 13.2 \\
\hline Right ulnar nerve & 4.2 & 2.7 & 23.8 \\
\hline Right sural nerve & No response & No response & No response \\
\hline Right superior peroneal nerve & No response & No response & No response \\
\hline \multicolumn{4}{|l|}{ F-wave } \\
\hline Right ulnar nerve & No response & & \\
\hline Right tibial nerve & No response & & \\
\hline
\end{tabular}

As the lesions were bilateral symmetry, we selected the right limbs

were first found in a CIDP patient with severe pain [11]. Apart from that, clinical features were quite similar to those of patients with other paranodal antibodies [12]. However, our patient did not have neuropathic pain, which is similar to the cases reported from Italy [12]. Another study showed that two patients with immunoglobulin (Ig) G4 anti Caspr1 antibodies had cranial nerve involvement and respiratory failure [7]. In a large cohort of subjects with possible CIDP, the antibodies against the node of Ranvier proteins were detected in less than $2 \%$ of patients [7]. However, antibodies against Caspr1 have only been reported in less than ten CIDP patients, and larger studies are needed to ascertain the specific features associated with these antibodies [7, 11, 12].

Anti-Caspr1 IgG4 had a function-blocking activity that inhibited the interaction of CNTN1/Caspr1and NF155-expressing cells and enabled these auto antibodies to dismantle the axoglial interactions and penetrate the paranodal regions [12]. Intravenous immunoglobulin has been established as the first choice of treatment for CIDP. However, CIDP associated with IgG4 antibodies against the node of Ranvier proteins did not respond to intravenous immunoglobulin therapy. Due to the limited methods, it was difficult to differentiate the IgG subtype in our hospital: we suspected the antibody was IgG4 subtype because of our patient's lack of response to intravenous immunoglobulin therapy. Plasma exchange and steroid pulse therapy were performed when intravenous immunoglobulin was not sufficiently effective. Nevertheless, rituximab treatment was needed to achieve clinical stability and the disappearance of the autoantibodies. In addition, our patient was found with bile duct hamartomas in the liver, which is rare and a type of ductal plate malformation [13, 14]. The pathogenesis of the lesions might be associated with ischemia, inflammation, or genetic anomalies $[13,14]$. No relevant literature has been reported on bile duct hamartomas in liver and anti-Caspr1 CIDP. It is well known that nearly half of females presenting with anti-Nmethyl-D-aspartic acid (NMDA) receptor (NMDAR) encephalitis had associated ovarian teratoma $[15,16]$. Furthermore, almost all of them had positive antiNMDAR antibody $[15,16]$. Therefore, in our case, we suspected there were possible associations between bile duct hamartomas in liver and anti-Caspr1 CIDP. Further studies are needed to validate the correlation.

\section{Conclusions}

It appears advisable to test for antibodies against node of Ranvier proteins in subjects with CIDP resistant to intravenous immunoglobulin. Although the frequency of these antibodies are rare, they have important diagnostic value and therapeutic implications as this condition does not usually respond to intravenous immunoglobulin, but may improve with plasma exchange and rituximab treatment. 

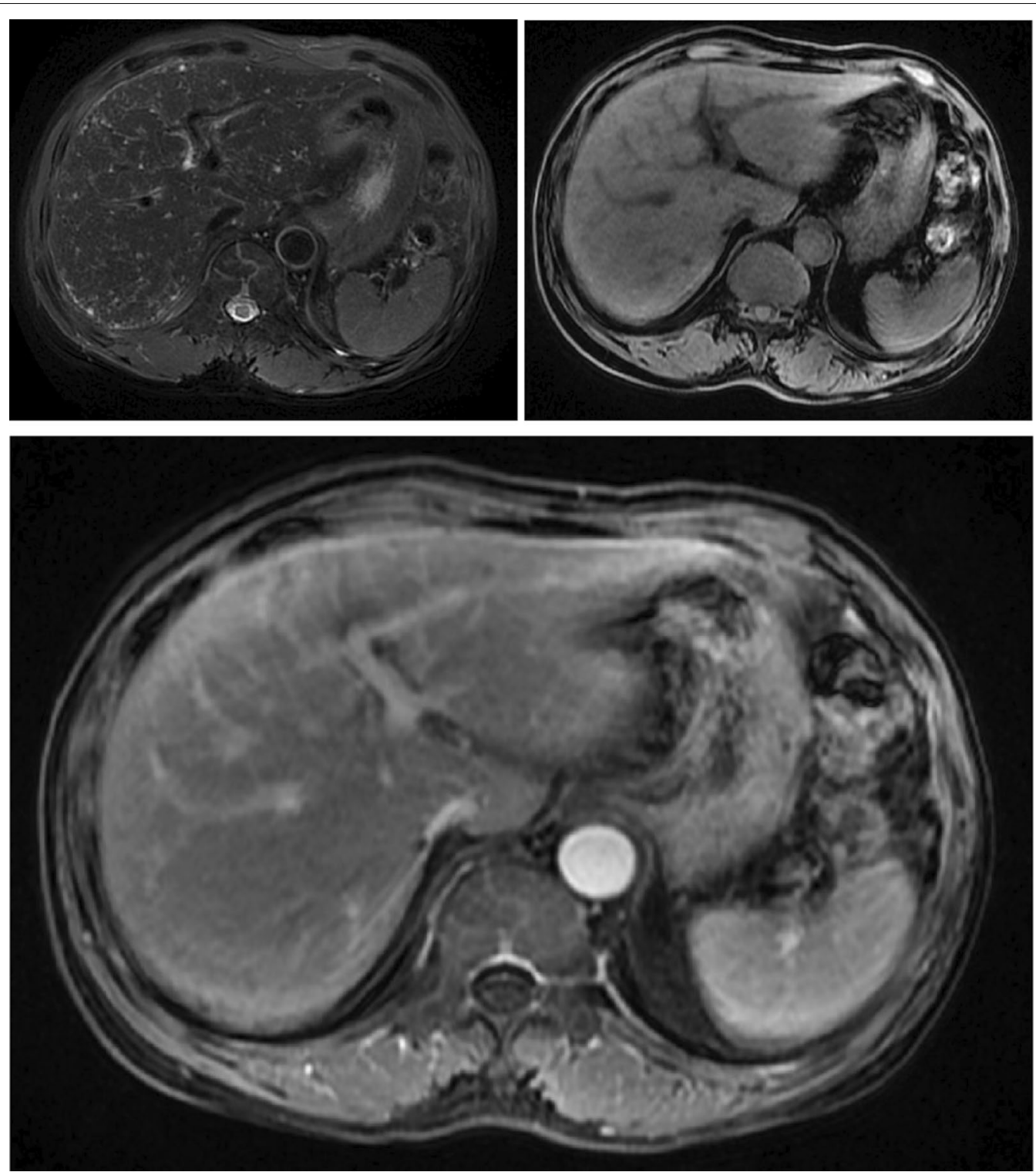

Fig. 1 Enhanced magnetic resonance imaging of the liver. The liver images before and after contrast injection showed diffuse intrahepatic lesions

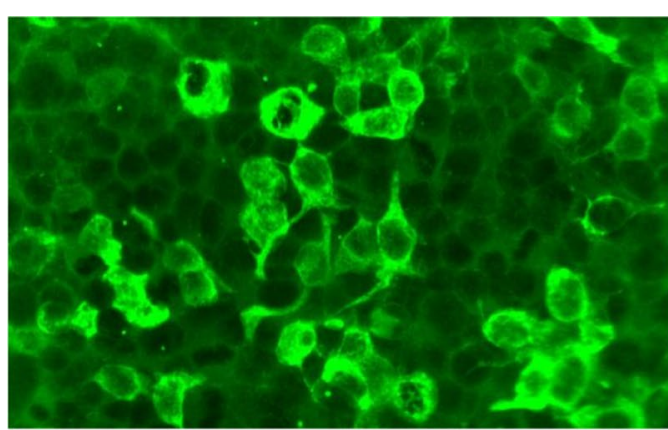

Caspr1 IgG

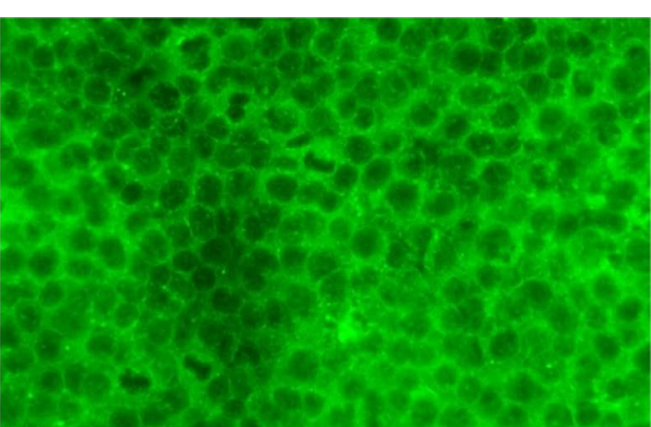

Control

Fig. 2 Detection of anti-Caspr1 antibody in our patient with CIDP. Serum sample from our patient was tested for auto antibodies against Caspr1 using a cell-based binding assay 


\section{Abbreviations}

CIDP: Chronic inflammatory demyelinating polyneuropathy; Caspr1: Anti-contactin-associated protein 1; CNTN1: Contactin-1; CNTN2: Contactin-2; NF155: Neurofascin 155; NF186: Neurofascin 186; MRI: Magnetic resonance imaging; ANCA: Antineutrophil cytoplasmic antibody; ANA: Antinuclear antibody; MBP: Myelin basic protein; MOG: Myelin oligodendrocyte glycoprotein; AQP4: Aquaporin-4; PNS: Paraneoplastic neurological syndromes.

\section{Acknowledgements}

The authors were grateful to surveyed patients.

\section{Authors' contributions}

$\mathrm{SH}$ and $\mathrm{YH}$ designed the study and prepared the manuscript. QD supervised the study and revised the manuscript. All authors read and approved the final manuscript.

\section{Funding}

Not applicable.

\section{Availability of data and materials}

The data underlying this article will be shared on reasonable request to the corresponding author.

\section{Declarations}

\section{Ethics approval and consent to participate}

The study was approved by the Ethics Committee of the hospital. Informed consent was received from the patient.

\section{Consent for publication}

Written informed consent was obtained from the patient for publication of this case report and any accompanying images. A copy of the written consent is available for review by the Editor-in-Chief of this journal.

\section{Competing interests}

The authors declared no conflict of interests.

\section{Author details}

1 Department of Gastroenterology, The Second Affiliated Hospital, Zhejiang University School of Medicine, Hangzhou, Zhejiang, China. ${ }^{2}$ Department of Neurology, The Second Affiliated Hospital, Zhejiang University School of Medicine, 88 Jiefang Road, Hangzhou 310000, Zhejiang, China.

Received: 18 March 2021 Accepted: 17 January 2022

Published online: 10 February 2022

\section{References}

1. Bunschoten C, Jacobs BC, Van den Bergh PYK, et al. Progress in diagnosis and treatment of chronic inflammatory demyelinating polyradiculoneuropathy. Lancet Neurol. 2019. https://doi.org/10.1016/S1474-4422(19) 30144-9.

2. Lehmann HC, Burke D, Kuwabara S. Chronic inflammatory demyelinating polyneuropathy: update on diagnosis, immunopathogenesis and treatment. J Neurol Neurosurg Psychiatry. 2019. https://doi.org/10.1136/ jnnp-2019-320314.

3. Querol L, Devaux J, Rojas-Garcia R, et al. Autoantibodies in chronic inflammatory neuropathies: diagnostic and therapeutic implications. Nat Rev Neurol. 2017;13:533-47. https://doi.org/10.1038/nrneurol.2017.84

4. Delmont E, Manso C, Querol L, et al. Autoantibodies to nodal isoforms of neurofascin in chronic inflammatory demyelinating polyneuropathy. Brain. 2017. https://doi.org/10.1093/brain/awx124.

5. Pascual-Goñi E, Fehmi J, Lleixà C, et al. Antibodies to the Caspr1/contactin-1 complex in chronic inflammatory demyelinating polyradiculoneuropathy. Brain. 2021;144(4):1183-96. https://doi.org/10.1093/brain/awab0 14.

6. Querol L, Nogales-Gadea G, Rojas-Garcia R, et al. Antibodies to contactin-1 in chronic inflammatory demyelinating polyneuropathy. Ann Neurol. 2013. https://doi.org/10.1002/ana.23794.
7. Delmont E, Brodovitch A, Kouton L, et al. Antibodies against the node of Ranvier: a real-life evaluation of incidence, clinical features and response to treatment based on a prospective analysis of 1500 sera. J Neurol. 2020. https://doi.org/10.1007/s00415-020-10041-z.

8. Hughes RAC, Bouche P, Cornblath DR, Evers E, Hadden RDM. European Federation of Neurological Societies/Peripheral Nerve Society guideline on management of chronic inflammatory demyelinating polyradiculoneuropathy: report of a joint task force of the European Federation of Neurological Societies and the Peripher. Eur J Neurol. 2006. https://doi. org/10.1111/j.1468-1331.2006.01278.x.

9. Mathey EK, Garg N, Park SB, et al. Autoantibody responses to nodal and paranodal antigens in chronic inflammatory neuropathies. J Neuroimmunol. 2017. https://doi.org/10.1016/j.jneuroim.2017.05.002.

10. Tang L, Huang Q, Qin Z, et al. Distinguish CIDP with autoantibody from that without autoantibody: pathogenesis, histopathology, and clinical features. J Neurol. 2020. https://doi.org/10.1007/s00415-020-09823-2.

11. Doppler K, Appeltshauser L, Villmann C, et al. Auto-antibodies to contactin-associated protein 1 (Caspr) in two patients with painful inflammatory neuropathy. Brain. 2016. https://doi.org/10.1093/brain/aww189.

12. Cortese A, Lombardi R, Briani C, et al. Antibodies to neurofascin, contactin-1, and contactin-associated protein 1 in CIDP: clinical relevance of IgG isotype. Neurol Neuroimmunol neuroinflammation. 2020. https://doi.org/ 10.1212/NXI.0000000000000639.

13. Torbenson MS. Hamartomas and malformations of the liver. Semin Diagn Pathol. 2019. https://doi.org/10.1053/j.semdp.2018.11.005.

14. Laing ADP, Gibson RN. MRI of the liver. J Magn Reson Imaging. 1998. https://doi.org/10.1002/jmri.1880080213.

15. Kaneko A, Kaneko J, Tominaga N, et al. Pitfalls in clinical diagnosis of anti-NMDA receptor encephalitis. J Neurol. 2018. https://doi.org/10.1007/ s00415-018-8749-3.

16. lizuka T, Sakai F. Anti-nMDA receptor encephalitis-clinical manifestations and pathophysiology. Brain Nerve. 2008;60(9):1047-60.

\section{Publisher's Note}

Springer Nature remains neutral with regard to jurisdictional claims in published maps and institutional affiliations.
Ready to submit your research? Choose BMC and benefit from:

- fast, convenient online submission

- thorough peer review by experienced researchers in your field

- rapid publication on acceptance

- support for research data, including large and complex data types

- gold Open Access which fosters wider collaboration and increased citations

- maximum visibility for your research: over $100 \mathrm{M}$ website views per year

At BMC, research is always in progress.

Learn more biomedcentral.com/submissions 